\title{
Serum Levels of Trace Elements in Patients with Testicular Cancers
}

Mehmet Kaba ${ }^{1}$, Necip Pirinççi ${ }^{1}$, Mehmet Bilgehan Yüksel ${ }^{2}$, İlhan Geçit ${ }^{1}$, Mustafa Güneş ${ }^{1}$, Murat Demir ${ }^{1}$, HurremTuran Akkoyun ${ }^{3}$, Halit Demir ${ }^{4}$

${ }^{1}$ Department of Urology,Faculty of Medicine,Yuzuncu Yil University, Van, Turkey; ${ }^{2}$ Department of Urology,Faculty of Medicine, Celal Bayar University, Manisa, Turkey; ${ }^{3}$ Department of Veterinaryand HealthSciences, Çiçekdağ $\imath$ VocationalCollege, Ahi Evran University, Kırşehir, Turkey; ${ }^{4}$ Department of Chemistry, Faculty of Scienceand Art,Yuzuncu Yil University, Van, Turkey

\section{ABSTRACT}

Introduction: Trace elements are primary components of biological structures; however, they can be toxic when their concentrations are higher than those needed for biological functions.

Materials and Methods: In the present study serum levels of trace elements were measured in 30 patients (mean age was $26.9 \pm 11.2$ years) newly diagnosed with germ cell testicular cancer and 32 healthy volunteers (mean age: $27.4 \pm 10.8$ ) by using furnace atomic absorption spectrophotometer. Serum samples were stored at $-20^{\circ} \mathrm{C}$ until assays. Results: In patients with germ cell testicular cancer, the diagnosis was seminoma in 15, mix germ cell tumor in 7, embryonal carcinoma in 4, yolk sac tumor in 2 and teratoma in 2 patients. There was stage I testicular tumor in 19 patients $(63.3 \%)$ while stage II in 6 patients (20.0\%), stage IIIA in 4 patients (13.3\%) and stage IIIC in one patient (3.4\%). It was found that serum $\mathrm{Co}, \mathrm{Cu}, \mathrm{Mg}$ and $\mathrm{Pb}$ levels were increased $(\mathrm{p}<0.05)$, whereas $\mathrm{Fe}$, $\mathrm{Mn}$, and $\mathrm{Zn}$ levels were decreased in patients with testicular cancer $(\mathrm{p}<0.05)$.

Conclusions: These alterations may be important in the pathogenesis of testicular cancers; however, further prospective studies are needed to identify the relationship between testicular cancer and trace elements.

\section{ARTICLE INFO}

Key words:

Testicular Neoplasms; Trace

Elements; Tumor Markers,

Biological

Int Braz J Urol. 2015; 41: 1101-07

Submitted for publication:

September 15, 2014

Accepted after revision: June 10, 2015

\section{INTRODUCTION}

Testicular cancers are the most commonly seen cancers in men aged 15-40 years (1). They comprise $1 \%$ of all cancers in men. Germ cell tumors comprise $90-95 \%$ of all primary testicular tumors. In the past, overall survival rate was approximately $10 \%$, while it increased up to $90 \%$ by advances in tumor markers and imaging techniques, and cisplatin-based chemotherapy regimens. The incidence of testicular cancer varies according to race and socioeconomic status. The likelihood of incident testicular cancer is higher in Scandinavian countries, while it is lower in Asian countries (2).

The trace elements are primary components of biological structures; however, they can exert toxic effect when their concentrations are higher than those needed for biological functions. Moreover, the toxicity can also be true for other non-essential elements which have very similar atomic properties and ability to mimic the reactivity of trace elements. Thus, this above-mentioned 
toxicity/duality leads biological system to develop ability of recognizing and delivering the metal to its target without enabling it to involve in toxic reactions $(3,4)$. Proteins are the primary compounds involved in this recognition and transport. The majority of the associations between a trace element and other biological molecules result in undesirable chemical modifications in these molecules.

In living organisms, biological mechanisms have been developed in order to use vital trace elements including zinc and copper and to minimize toxic effects of heavy metals such as cadmium, mercury and lead (5). Oxidative processes are most intensive in a background where an imbalance is present in trace elements involved in the structure of enzymes accounted for antioxidant defense (6). Alterations in the ion content of trace elements including iron, copper and zinc can affect activity of antioxidants (7). In several cancers, it has been reported that significant differences occur in the normal distribution of iron, copper and zinc (8). In some trials, serum $\mathrm{Cu} / \mathrm{Zn}$ ratio was employed as chemoprophylaxis (9). Moreover, it has been also used to evaluate and assess the prognosis in patients with cancer $(10,11)$.

In the present study, serum levels of trace elements were measured and it was found that $\mathrm{Mn}$, $\mathrm{Co}, \mathrm{Cu}, \mathrm{Mg}, \mathrm{Fe}$ and $\mathrm{Zn}$ concentrations were altered in sera of the patients with testicular cancer in comparison to healthy subjects.

\section{MATERIALS AND METHODS}

The study included 30 men with germ cell testicular cancer. Mean age was $26.9 \pm 11.2$ years. All patients were lifetime non-smokers and had no history of alcohol addiction, drug abuse, antioxidant use and metabolic diseases. No comorbid disease was present in any of the patients. All patients had newly diagnosed testicular cancer and preoperative blood samples were taken. Thirty two healthy male subjects (mean age: $27.4 \pm 10.8$ ) were randomly selected as controls among volunteers who had no history of smoking, alcohol consumption, drug or antioxidant use, and known comorbid disease. The patient and control groups had similar socioeconomic status.

According to 2009 TNM tumor staging system, there was stage I testicular tumor in
19 patients $(63.3 \%)$ while stage II in 6 patients (20.0\%), stage IIIA in 4 patients (13.3\%) and stage IIIC in one patient (3.4\%). The study was conducted in accordance to Helsinki Declaration, 1989 Revision. All participants gave written informed consent before participation in the study.

\section{Blood Samples}

Blood samples were drawn at morning after 12 hours fasting and stored on ice at $4^{\circ} \mathrm{C}$. Then, sera were separated by centrifugation at $3000 \mathrm{rpm}$ for 10 minutes. Serum samples were stored at $-20^{\circ} \mathrm{C}$ until assays.

\section{Measurements of Mineral-Heavy Metal Levels}

Two milliliters of HNO3/H2O2 mixture (2:1) were added to $0.7 \mathrm{~g}$ of the serum samples. The mixture was placed into the water bath at $70^{\circ} \mathrm{C}$ for $30 \mathrm{~min}$ and stirred occasionally. Then, one $\mathrm{mL}$ of the same acid mixture was added, and the mixture was transferred into a Teflon vessel bomb for the microwave oven. The bomb was closed, and the solution was placed inside the microwave oven. Radiation was applied for $3 \mathrm{~min}$ at $450 \mathrm{~W}$. After addition of $0.5 \mathrm{~mL}$ of the same acid mixture, radiation was repeated for $3 \mathrm{~min}$. After cooling for $5 \mathrm{~min}, 2.0 \mathrm{~mL}$ of $0.1 \mathrm{~mol} / \mathrm{L} \mathrm{HNO}^{3}$ was added, and the solution was transferred to a Pyrex tube. After centrifugation, the clear solution was used to determine $\mathrm{Mn}, \mathrm{Cd}, \mathrm{Cu}, \mathrm{Pb}, \mathrm{Fe}, \mathrm{Mg}, \mathrm{Co}$ and $\mathrm{Zn}$ levels. They were measured by using atomic absorption spectrophotometer technique with a UNICAM-929 spectrophotometer (Unicam Ltd, York Street, Cambridge, UK).

\section{Statistical Analysis}

All data were analyzed by using SPSS for Windows version 13.0. Descriptive statistics of the traits evaluated were expressed as mean, standard deviation, minimum and maximum values. Mann-Whitney U test was used for intergroup comparisons. $\mathrm{P}<0.05$ was considered as significant.

\section{RESULTS}

There was seminoma in 15, mix germ cell tumor in 7, embryonal carcinoma in 4, yolk sac 
tumor in 2 and teratoma in 2 patients. The demographic characteristics are presented Table- 1 . Trace elements levels are presented in Table-2. No statistical difference was detected between patients with testicular cancer and controls regarding age and body mass index (BMI).

Trace element levels were compared between groups. It was found that $\mathrm{Co}, \mathrm{Cu}, \mathrm{Mg}$ and $\mathrm{Pb}$ levels were significantly higher in the patient group compared to the controls. It was also found that $\mathrm{Zn}, \mathrm{Fe}$ and Mn levels were significantly lower in the patient group compared to controls. Cd levels were found to be higher in patients with testicular tumors compared to controls, but this didn't reach statistical significance.

\section{DISCUSSION}

Traces elements are accepted as essential components of biological structures, which play complex roles in the cancer development or inhibition. There are many questions regarding their essential and toxic effects on human health above the concentrations needed for their biological functions. In this context, there are conflicting results in the literature $(12,13)$.

Table 1 - Demographic characteristics.

\begin{tabular}{lccc}
\hline Demographic characteristics & Patients $(n=30)$ & Control $(n=32)$ & $p$ Value \\
\hline Age $($ years $)($ mean $\pm S D)$ & $26.9 \pm 11.2$ & $27.4 \pm 10.8$ & $>0.05$ \\
BMI $\left(\mathrm{kg} / \mathrm{m}^{2}\right)$ & $27.0 \pm 2.7$ & $28.0 \pm 2.1$ & $>0.05$ \\
\hline
\end{tabular}

Table 2 - Descriptive Statistics and Comparison Results According to the Groups for Specifications.

\begin{tabular}{|c|c|c|c|c|c|c|c|}
\hline & & $\mathrm{N}$ & Mean & Std. Dev. & Min. & Max. & $p$ \\
\hline \multirow[t]{2}{*}{$\mathrm{Cd}$} & Patient & 30 & 0.008636 & 0.020831 & 0.00194 & 0.07781 & 0.083 \\
\hline & control & 32 & 0.001109 & 0.000114 & 0.00101 & 0.00135 & \\
\hline \multirow[t]{2}{*}{ Co } & Patient & 30 & 0.002506 & 0.001108 & 0.00107 & 0.00432 & 0.001 \\
\hline & control & 32 & 0.001102 & 0.000986 & 0.00101 & 0.00143 & \\
\hline \multirow[t]{2}{*}{$\mathrm{Cu}$} & Patient & 30 & 1.0944 & 0.3992 & 0.01 & 1.84 & 0.001 \\
\hline & control & 32 & 0.84 & 0.13474 & 0.52 & 0.98 & \\
\hline \multirow[t]{2}{*}{$\mathrm{Fe}$} & Patient & 30 & 0.917971 & 0.404285 & 0.0433 & 1.588 & 0.001 \\
\hline & control & 32 & 2.430144 & 0.189439 & 2.0121 & 2.7998 & \\
\hline \multirow[t]{2}{*}{$\mathrm{Mg}$} & Patient & 30 & 24.4 & 2.88236 & 15.83 & 28.47 & 0.001 \\
\hline & control & 32 & 0.7527 & 0.18918 & 0.11 & 0.99 & \\
\hline \multirow[t]{2}{*}{ Mn } & Patient & 30 & 0.010167 & 0.008136 & 0.00145 & 0.03986 & 0.001 \\
\hline & control & 32 & 0.7527 & 0.189182 & 0.11114 & 0.98991 & \\
\hline \multirow[t]{2}{*}{$\mathrm{Pb}$} & Patient & 30 & 0.035 & 0.019655 & 0.00276 & 0.07757 & 0.001 \\
\hline & control & 32 & 0.001204 & 0.000131 & 0.001 & 0.0015 & \\
\hline \multirow[t]{2}{*}{ Zn } & Patient & 30 & 0.90998 & 0.330196 & 0.036 & 1.72 & 0.001 \\
\hline & control & 32 & 2.96368 & 0.443655 & 2.125 & 4.021 & \\
\hline
\end{tabular}


$\mathrm{Mn}$ is an essential element which is required for several enzyme activities. It has a major role in the antioxidant defense system and comprises part of SOD enzyme (14). Therefore, it can be suggested that decreased serum Mn concentrations with disturbance of antioxidant mechanism can make target organs sensitive to carcinogens. Decreased serum Mn concentrations were reported in patients with bladder and renal cancers $(15,16)$. Our study showed that serum Mn concentrations were lower in patients with testicular cancer compared to controls. According to our hypothesis, Mn can result in oxidant/antioxidant imbalance in patients with testicular cancer, as being a trace element affecting oxidation status.

Zinc plays an anti-carcinogenic role through structural stabilization of deoxyribonucleic acid (DNA), ribonucleic acid (RNA), and ribosome. Zinc is also important in the functions of several transcription factors and proteins that are involved in the recognition of specific DNA sequences and regulation of gene transcription. Zinc has a protective effect against free-radical injury (17). In previous studies, it has been reported that serum $\mathrm{Zn}$ concentrations were decreased in patients with ovarian, cervical, bladder and renal cancer (15-19). It seems that it is necessary to determine serum zinc levels in patients with ovarian cancer in comparison with healthy controls in order to fully elucidate the relationship between serum $\mathrm{Zn}$ levels and ovarian cancer. In addition, in a previous study, there were normal or elevated zinc concentrations only in the sera of the cases with primary liver cancer in contrast to decreased serum zinc levels in remaining cases, suggesting a differential sign favoring transformation from hepatocirrhosis to cancer (20). Our study demonstrated decreased $\mathrm{Zn}$ concentrations in patients with testicular cancer compared to controls.

Fe is a trace element which is physiologically essential but dangerous in biochemical aspect. Either excess or deficiency of Fe can lead to oxidative DNA damage, although it is an important nutritional element (21). Moreover, it was proposed that low iron levels may have a role in the prevention of infection and cancer (22).

There is substantial evidence supporting the hypothesis of a relationship between testicular cancer and disruption of iron metabolism and that testicular cancer may be a clinical manifestation of iron-induced testicular damage, presumably through an underlying free-radical mechanism (23). In our study, results indicated that there was a significant difference in serum Fe levels between patient and control groups.

Physiological $\mathrm{Cd}$ doses lead to an increased endothelial permeability through inhibition of endothelial proliferation and induction of cell death mediated by DNA damage, which is also inhibited by zinc (24). It has been reported that doubling of soil cadmium is associated with an increased risk for lung cancer by 57\% (25). It was also shown that serum Cd levels were increased in patients with bladder cancer (3). In cadmium carcinogenicity, proto-oncogene activation, tumor suppressor gene inactivation, disrupted cell adhesion and inhibition of DNA repair are the implied cellular and molecular mechanisms (26, 27). In addition, it has been reported that elevated $\mathrm{Cd}$ concentration may result in prostate, kidney and lung cancers (28). In the past decade, it has been reported that the injection of cadmium metal powder and various cadmium compounds induce sarcoma in local and interstitial cell testicular tumor in a systemic manner (29). In our study, Cd levels were found to be higher in patients with testicular cancer compared to controls. However, the difference didn't reach statistical significance.

In our study, it was also demonstrated that serum levels of $\mathrm{Pb}, \mathrm{Co}, \mathrm{Cu}$ and $\mathrm{Mg}$ were increased when compared to controls. It is well-known that $\mathrm{Pb}$ and $\mathrm{Cd}$ are toxic and carcinogenic metals (25). It has been suggested that $\mathrm{Pb}$ has a predisposing role in the carcinogenesis with inhibition of DNA synthesis and repair, oxidative injury and interaction with DNA-binding proteins and tumor suppressor proteins $(30,31)$. Exposure to inorganic lead at early life induces teratoma and pre-neoplasm of renal and urinary bladder (32). Recent research indicated negative health consequences of lower level of lead exposure, including impaired functions of renal tubular cells, inhibition of sperm formation, fetal damage, decelerated velocity of motor nerves, and central nervous system dysfunction as well as hypertension and other cardiovascular diseases $(33,34)$. It was also sho- 
wn that $\mathrm{Pb}$ levels were significantly increased in patients with malignant glioma compared to controls (35). In our study, Pb levels were found to be significantly higher in the patient group compared to controls.

Co is a constituent of vitamin B12 in humans. In human studies, evidence is inconclusive regarding relationship between inhalational exposure to cobalt and cancer. In the only available study on oral exposure to cobalt, no correlation was reported between cobalt and cancer deaths. In a study on workers refining and processing cobalt and sodium, it was shown that there was an increase in deaths from lung cancer in workers exposed to cobalt. Effects of exposure to cobalt salts were investigated in only one study. Preliminary results indicated an increased risk for lung cancer in those working at cobalt production, but follow-up didn't show any increase in the risk for cancer (36). However, that study was limited by the small number of workers who developed cancer. In our study, Co levels were found to be significantly higher in the patient group compared to controls.

$\mathrm{Cu}$ plays a role in the production of hemoglobin, myelin, collagen and melanin as an essential nutrient (4). In recent studies, it was shown that normal immune function requires adequate $\mathrm{Cu}$ intake $(3,4)$. It is well-known that serum $\mathrm{Cu}$ levels increase in several malignancies such as osteosarcoma, gastrointestinal tumors and lung cancer (37). In some studies, it was shown that there was an increase in $\mathrm{Cu}$ levels within tumor cells or lung epithelial lining fluid of patients with lung cancer $(38,39)$. In our study, serum Cu levels were found to be significantly higher in the patient group compared to controls.

The observed effects of magnesium on either tumor transplant-or chemical-induced cancers depended on the duration of $\mathrm{Mg}$ supplementation or deficiency (40). Optimal $\mathrm{Mg}$ supplementation may have prophylactic effects against some neoplasms, but $\mathrm{Mg}$ alone isn't recommended for therapeutic purposes as cancer cells have also high metabolic requirements (40). Recently, in rats, it was shown that $\mathrm{Mg}$ supplementation inhibited increased DNA synthesis at colon epithelium. In that study, it was suggested that the finding might be related to suppression of oncogene-induced bowel carcinogenesis by $\mathrm{Mg}$ (41). In our study, serum $\mathrm{Mg}$ levels were found to be significantly higher in patients with testicular cancer compared to controls.

In our study, serum levels of trace elements were assessed in germ cell testicular cancer. Serum levels of trace elements can differ in different germ cell testicular cancer as in serum levels of tumor markers. Further studies are needed to evaluate this issue. Germ cell testicular cancers (other than choriocarcinoma) initially spread to retroperitoneal lymph nodes. Retrospective studies with larger series which compare early stage, non-metastatic and metastatic tumors are necessary in order to investigate effects of metastasis on alterations in serum trace element levels.

In conclusion, an association was observed between testicular cancer and trace elements in the present study. We also think that increases in $\mathrm{Co}, \mathrm{Cu}, \mathrm{Mg}$ and $\mathrm{Pb}$ levels and decreases in $\mathrm{Zn}, \mathrm{Mn}$ and Fe levels can play important roles in the induction of testicular cancers. However, future prospective studies on the reasons of alteration in the serum concentrations of trace elements in patients with testicular cancer seem to be well grounded. Further prospective studies are needed to clarify the relationship between various stages of testicular cancer and serum levels of trace elements.

\section{CONFLICT OF INTEREST}

None declared.

\section{REFERENCES}

1. Chia VM, Quraishi SM, Devesa SS, Purdue MP, Cook MB, McGlynn KA. International trends in the incidence of testicular cancer, 1973-2002. Cancer Epidemiol Biomarkers Prev. 2010; 19:1151-9.

2. Greenlee RT, Hill-Harmon MB, Murray T, Thun M. Cancer statistics, 2001. CA Cancer J Clin. 2001; 51:15-36. Erratum in: CA Cancer J Clin 2001; 51:144.

3. Gecit I, Kavak S, Demir H, Gunes M, Pirincci N, Cetin C, et al. Serum trace element levels in patients with bladder cancer. Asian Pac J Cancer Prev. 2011; 12:3409-13.

4. Sayır F, Kavak S, Meral I, Demir H, Cengiz N, Cobanoğlu U. Effects of crush and axotomy on oxidative stress and some trace element levels in phrenic nerve of rats. Brain Res Bull. 2013; 92:84-8. 
5. Solioz M, Odermatt A, Krapf R. Copper pumping ATPases: common concepts in bacteria and man. FEBS Lett. 1994; 346:44-7.

6. Hoekstra WG, Suttie JW, Ganther HG, Mentz W. Trace elements metabolism in animals, University Park Press, Baltimore. 1974;2:61.

7. Yelinova V, Glazachev Y, Khramtsov V, Kudryashova L, Rykova V, Salganik R. Studies of human and rat blood under oxidative stress: changes in plasma thiol level, antioxidant enzyme activity, protein carbonyl content, and fluidity of erythrocyte membrane. Biochem Biophys Res Commun. 1996; 221:300-3.

8. Spartz L, Bloom AD. Biological consequences of oxidative stress: implications for cardiovascular disease and carcinogenesis. Oxford University Press, New York, 1992; pp. 138-61.

9. Li Y, Xue Q, Chen L, Chen H, Chai C, Shi B, et al. Research on relationships of gastric cancer with serum trace elements, Helicobacter pylori and COX-2 in gastric tissue. Sheng Wu Yi Xue Gong Cheng Xue Za Zhi. 2004; 21:107-10.

10. Shukla VK, Adukia TK, Singh SP, Mishra CP, Mishra RN. Micronutrients, antioxidants, and carcinoma of the gallbladder. J Surg Oncol. 2003; 84:31-5.

11. Mazdak H, Yazdekhasti F, Movahedian A, Mirkheshti $\mathrm{N}$, Shafieian M. The comparative study of serum iron, copper, and zinc levels between bladder câncer patients and a control group. Int Urol Nephrol. 2010; 42:89-93.

12. Piccinini L, Borella P, Bargellini A, Medici $\mathrm{Cl}$, Zoboli A. A case-control study on selenium, zinc, and copper in plasma and hair of subjects affected by breast and lung cancer. Biol Trace Elem Res. 1996; 51:23-30.

13. Zowczak M, Iskra M, Torliński L, Cofta S. Analysis of serum copper and zinc concentrations in cancer patients. Biol Trace Elem Res. 2001; 82:1-8.

14. Johnson S. The possible crucial role of iron accumulation combined with low tryptophan, zinc and manganese in carcinogenesis. Med Hypotheses. 2001; 57:539-43.

15. Gecit İ, Kavak S, Meral I, Pirinçci N, Güneş M, Demir H, et al. Effects of shock waves on oxidative stress, antioxidant enzyme and element levels in kidney of rats. Biol Trace Elem Res. 2011; 144:1069-76.

16. Pirincci N, Gecit I, Gunes M, Kaba M, Tanik S, Yuksel $M B$, et al. Levels of serum trace elements in renal cell carcinoma cases. Asian Pac J Cancer Prev. 2013; 14:499502.

17. Wu T, Sempos CT, Freudenheim JL, Muti P, Smit E. Serum iron, copper and zinc concentrations and risk of cancer mortality in US adults. Ann Epidemiol. 2004; 14:195-201.

18. Cunzhi H, Jiexian J, Xianwen Z, Jingang G, Shumin Z, Lili D. Serum and tissue levels of six trace elements and copper/zinc ratio in patients with cervical cancer and uterine myoma. Biol Trace Elem Res. 2003; 94:113-22.
19. Yaman M, Kaya G, Simsek M. Comparison of trace element concentrations in cancerous and noncancerous human endometrial and ovary tissues. Int J Gynecol Cancer. 2007; 17:220-8.

20. Karlinskī VM, Bogomolova GG. Change in zinc metabolism in malignant neoplasms. Vopr Onkol. 1985; 31:25-9.

21. Ames BN. DNA damage from micronutrient deficiencies is likely to be a major cause of cancer. Mutat Res. 2001; 475:7-20.

22. Weinberg ED. Cellular iron metabolism in health and disease. Drug Metab Rev. 1990; 22:531-79.

23. Crawford RD. Proposed role for a combination of citric acid and ascorbic acid in the production of dietary iron overload: a fundamental cause of disease. Biochem Mol Med. 1995; 54:1-11.

24. Messner B, Knoflach M, Seubert A, Ritsch A, Pfaller K, Henderson $B$, et al. Cadmium is a novel and independent risk factor for early atherosclerosis mechanisms and in vivo relevance. Arterioscler Thromb Vasc Biol. 2009; 29:1392-8.

25. Nawrot TS, Thijs L, Den Hond EM, Roels HA, Staessen JA. An epidemiological re-appraisal of the association between blood pressure and blood lead: a meta-analysis. J Hum Hypertens. 2002; 16:123-31.

26. Waalkes MP. Cadmium carcinogenesis. Mutat Res. 2003; 533:107-20.

27. Waisberg M, Joseph P, Hale B, Beyersmann D. Molecular and cellular mechanisms of cadmium carcinogenesis. Toxicology. 2003; 192:95-117.

28. Drasch G, Schöpfer J, Schrauzer GN. Selenium/cadmium ratios in human prostates: indicators of prostate cancer risk of smokers and nonsmokers, and relevance to the cancer protective effects of selenium. Biol Trace Elem Res. 2005; 103:103-7.

29. World Health Organızation Regional Office for Europe. Air quality guidelines, 2nd edn. World Health Organization, Copenhagen, Denmark. 2000.

30. Inskip PD, Linet MS, Heineman EF. Etiology of brain tumors in adults. Epidemiol Rev. 1995; 17:382-414.

31. Van Wijngaarden E, Dosemeci M. Brain cancer mortality and potential occupational exposure to lead: findings from the National Longitudinal Mortality Study, 1979-1989. Int J Cancer. 2006; 119:1136-44. Erratum in: Int J Cancer. 2007; 121:698.

32. Moulin JJ, Wild P, Romazini S, Lasfargues G, Peltier A, Bozec C, et al. Lung cancer risk in hard-metal workers. Am J Epidemiol. 1998; 148:241-8.

33. Landrigan PJ. Toxicity of lead at low dose. Br $\mathrm{J}$ Ind Med. 1989; 46:593-6.

34. Møller L, Kristensen TS. Blood lead as a cardiovascular risk factor. Am J Epidemiol. 1992; 136:1091-100.

35. Arslan M, Demir H, Arslan H, Gokalp AS, Demir C. Trace elements, heavy metals and other biochemical parameters in malignant glioma patients. Asian Pac J Câncer Prev. 2011; 12:447-51. 
36. Tokar EJ, Diwan BA, Waalkes MP. Early life inorganic lead exposure induces testicular teratoma and renal and urinary bladder preneoplasia in adult metallothionein-knockout mice but not in wild type mice. Toxicology. 2010;276:5-10.

37. Turecký L, Kalina P, Uhlíková E, Námerová S, Krizko J. Serum ceruloplasmin and copper levels in patients with primary brain tumors. Klin Wochenschr. 1984; 62:187-9.

38. Dìez M, Cerdàn FJ, Arroyo M, Balibrea JL. Use of the copper/zinc ratio in the diagnosis of lung cancer. Cancer. 1989; 63:726-30.
39. Mahabir S, Spitz MR, Barrera SL, Beaver SH, Etzel C, Forman MR. Dietary zinc, copper and selenium, and risk of lung cancer. Int J Cancer. 2007; 120:1108-15.

40. Collery P, Anghileri LJ, Coudoux P, et al. Magnesium and cancer: clinical data. Magnesium Bull. 1981; 3: 11-20.

41. Mori H, Morishita Y, Mori Y, Yoshimi N, Sugie S, Tanaka T. Effect of magnesium hydroxide on methylazoxymethanol acetate-induced epithelial proliferation in the large bowels of rats. Cancer Lett. 1992;62:43-8.

Correspondence address: Mehmet Kaba, MD

YuzuncuYil University, Faculty of Medicine,

Department of Urology

65000, Van, Turkey

Fax: + 90432 216-7519

E-mail: mehmetkaba@yahoo.com 